\title{
APLIKASI ALGORITMA BACKTRACKING UNTUK MENENTUKAN RUTE OPTIMAL DISTRIBUSI AIR ISI ULANG GONZALO DI KOTA AMBON
}

\section{The Application of Backtracking Algorithm to Determine Optimal Route Distribution of Gonzalo Refill Water in Ambon}

\author{
Jemsry E. Lakotany ${ }^{1}$, Elvinus R. Persulessy ${ }^{2}$, Yopi Andry Lesnussa ${ }^{3^{*}}$ \\ 1,2,3 Jurusan Matematika FMIPA Universitas Pattimura \\ Jl. Ir. M. Putuhena, Poka-Ambon, 97233, Maluku, Indonesia \\ e-mail: 1Jemsy_lakotany@yahoo.co.id ; ${ }^{3 *}$ yopi_a_lesnussa@yahoo.com \\ Corresponding author*
}

\begin{abstract}
Abstrak
Pendistribusian merupakan suatu penyaluran barang dari suatu lokasi asal ke lokasi tujuan, dimana dalam pendistribusian rute perjalanan merupakan suatu hal yang sangat penting karena dapat mempengaruhi waktu dan biaya dalam melakukan pendistribusian. Rute optimal merupakan suatu rute yang meminimalisir suatu jarak dan waktu tempuh. Penelitian ini menggunakan Algoritma Backtracking yang merupakan bagian dari metode Traveling salesman problem dalam pencarian rute terpendek atau jarak yang minimum. Pada penelitian ini bertujuan menerapkan algoritma Backtracking dalam pencarian rute/jalur minimum pendistribusian air isi ulang Gonzalo. Sehingga hasil yang diperoleh yaitu jalur distribusi air dengan rute terpendek di Kota Ambon, yaitu Gonzalo - Jln. Karang panjang - Jln. Pitu ina - Jln. Dr. Kayadoe - Terminal mardika - Jln. Wr. Supratman - Jln. A.Y. Patty - Jln. Said Perintah - Jln. Pattimura - Jln A. Yani - Gonzalo, dengan panjang rute perjalanan adalah $15,301 \mathrm{Km}$.
\end{abstract}

Kata Kunci: Algoritma Backtracking, traveling salesman problem, jalur optimum.

\begin{abstract}
Distribution is a delivery of goods from an original area to the destination area, wherein the distribution, the problem of travel routes is very important because it can affect the time and cost of doing the distribution. The optimal route itself is a route that minimizes the distance and travel time. This research using the Backtracking Algorithm as part of the Traveling salesman problem method in finding the shortest route or minimum distance. In this research, the Backtracking algorithm is applied to search the minimum route for Gonzalo refill water distribution. The results obtained are the path with the shortest route in Ambon City, such as: Gonzalo - Jln. Karang Panjang - Jln. Pitu ina - Jln. Dr. Kayadoe - Terminal mardika - Jln. Wr. Supratman - Jln. A.Y. Patty - Jln. Said Commands - Jln. Pattimura - Jln A. Yani - Gonzalo, with a long of travel route is 15,301 Km.
\end{abstract}

Keywords: Backtracking algorithm, traveling salesman problem, optimum path 


\section{PENDAHULUAN}

Pendistribusian merupakan suatu proses penyaluran barang atau produk dari suatu kota asal ke satu atau lebih kota tujuan. Semakin banyaknya kota tujuan yang dituju maka akan semakin banyak juga rute perjalanan yang dapat di tempuh dalam melakukan pendistribusian. Setiap rute yang ada memiliki jarak dan waktu tempuh yang berbeda sehingga pihak distributor harus cermat dalam memilih rute mana yang menguntungkan baik dari segi jarak maupun waktu. Dalam matematika sendiri pencarian rute yang optimal sudah sering dijumpai dalam Traveling Salesman Problem (TSP). TSP merupakan permasalahan suatu jaringan yang terdiri dari N kota, dimana seorang salesman harus mengunjungi semua kota dimana tiap kota hanya dikunjungi sekali, dan dia harus mulai dari dan kembali ke kota asal [1], [2], [3], [4]. Masalah TSP selalu berkaitan erat dengan masalah optimasi untuk memperoleh keuntungan maksimum [5], [6], dan mudah diselesaikan dengan bantuan aplikasi komputer [7], [8], [9]. Dengan berkembangnya ilmu matematika maka muncul bermacam-macam metode dalam pencarian rute optimal seperti Algoritma Backtracking [10], [11], [12], Algoritma Genetic [13], [14], [15], [16], Simulated Annealing [17][18], [19].

Metode Algoritma Backtracking biasa digunakan dalam pencarian rute yang optimal. Algoritma Backtracking sendiri merupakan Algoritma yang pertama kali diperkenalkan oleh D. H Lehmer pada tahun 1950 dimana Algoritma ini melakukan pencarian solusi persoalan secara sistematis pada semua kemungkinan solusi yang ada dan sering digunakan dalam beberapa penyelesaian masalah serta untuk memberikan kecerdasan buatan dalam game [20][21][22][23][24].

Masalah yang diteliti dalam artikel ini yaitu mengenai rute pendistribusian air isi ulang Gonzalo. Banyaknya pelanggan pada tempat - tempat yang berbeda sehingga penyaluran air isi ulang harus dilakukan distribusi ke tempat - tempat tersebut. Dimana dalam melakukan pendistribusian, air isi ulang Gonzalo tidak memiliki rute yang pasti dan hanya mengikuti jalur yang ada seperti Gonzalo, jalan Pitu Ina, jalan Karang Panjang, jalan WR. Supratman, jalan Pattimura, jalan A. Yani, jalan Dr. Kayadoe, jalan Said Perintah, jalan A.Y. patty, Terminal Mardika sehingga waktu dan jarak yang ditempuh tidak optimal. Maka dalam penelitian ini dihitung dan diteliti jalur/rute optimal dalam pendistribusian air isi ulang Gonzalo di Kota Ambon yang lebih optimal dari sisi waktu dan jarak.

\section{METODE PENELITIAN}

Penelititan ini bersifat studi kasus, dengan data yang digunakan yaitu data rute distribusi Air Isi Ulang Gonzalo di Kota Ambon. Metode yang digunakan yaitu metode Algoritma Backtracking. Berikut diagram alir algoritma Backtracking:

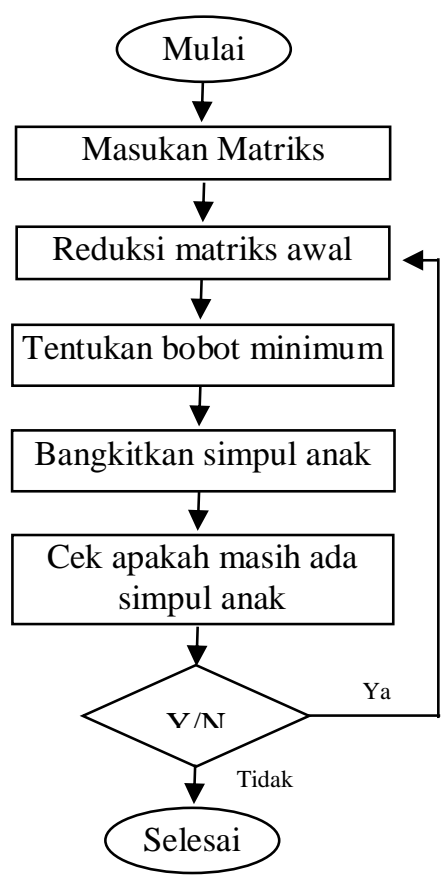

Gambar 1. Diagram Alir Algoritma Backtracking 


\section{HASIL DAN PEMBAHASAN}

\subsection{Data Penelitian}

Data yang diperlukan dalam penelitian ini adalah hasil pengumpulan data dari tempat pengisian Air Isi Ulang Gonzalo, dimana data yang diperoleh merupakan data mengenai nama pelanggan beserta alamatnya, karena terdapat beberapa pelanggan yang berada pada suatu wilayah yang sama maka data yang diperoleh kemudian dikelompokan berdasarkan nama jalannya sehingga data tersebut di bagi menjadi 10 daerah menurut nama jalannya dengan jarak antara setiap jalan dapat dilihat dari Tabel 1 dibawah ini.

Tabel 1. Data Jarak Tempuh Antar Jalan dalam Satuan Km

\begin{tabular}{|c|c|c|c|c|c|c|c|c|c|c|}
\hline & 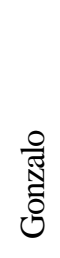 & 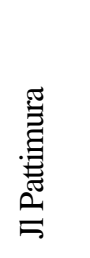 & $\begin{array}{l}\text { E } \\
\text { 元 } \\
\searrow \\
\varangle \\
=\end{array}$ & 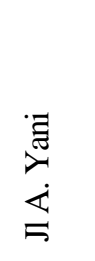 & 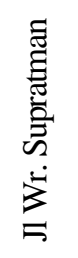 & 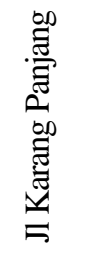 & 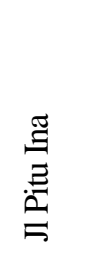 & 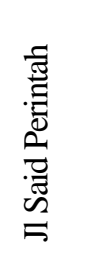 & 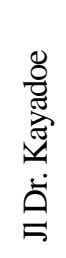 & 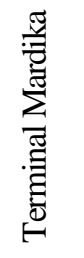 \\
\hline Gonzalo & 0 & 4.3 & 4.9 & 4.2 & 4.3 & 3 & 2.4 & 4.5 & 6.6 & 4.8 \\
\hline J1 Pattimura & 4.1 & 0 & 1 & 0.091 & 0.66 & 1.8 & 2.3 & 0.599 & 2.9 & 1.2 \\
\hline Jl A Y Patti & 4.9 & 1.1 & 0 & 1.1 & 1.7 & 2 & 2.8 & 0.887 & 2.4 & 0.888 \\
\hline J1 A. Yani & 4.2 & 1.2 & 0.917 & 0 & 1.8 & 2.8 & 3.6 & 0.67 & 2.8 & 1.7 \\
\hline Jl Wr. Supratman & 4.2 & 0.875 & 0.804 & 0.966 & 0 & 1.7 & 2.5 & 0.708 & 2.8 & 0.579 \\
\hline Jl Karang Panjang & 3 & 1.1 & 1.9 & 1.2 & 1.2 & 0 & 0.568 & 1.5 & 3.6 & 1.8 \\
\hline J1 Pitu Ina & 2.4 & 1.7 & 2.5 & 1.8 & 1.8 & 0.568 & 0 & 2.1 & 4.2 & 2.4 \\
\hline J1 Said Perintah & 4.5 & 0.669 & 0.408 & 0.76 & 1.3 & 2.3 & 3.1 & 0 & 2.1 & 1.2 \\
\hline Jl Dr. Kayadoe & 6.6 & 2.8 & 2.4 & 2.9 & 3.4 & 4.3 & 5.3 & 2.4 & 0 & 3.3 \\
\hline Terminal Mardika & 5.2 & 1.5 & 0.794 & 1.6 & 2.1 & 2.4 & 3.2 & 1.3 & 3.2 & 0 \\
\hline
\end{tabular}

\subsection{Penyelesaian dengan Algoritma Backtracking}

Dari data diatas maka jarak antara setiap tempat tujuan yang ada dapat direpresentasikan dalam bentuk suatu grafik, dimana setiap titik dari graf merepresentasikan tempat - tempat tujuan yang ada dan sisi - sisi nya merepresentasikan jarak antara setiap kota tujuan :

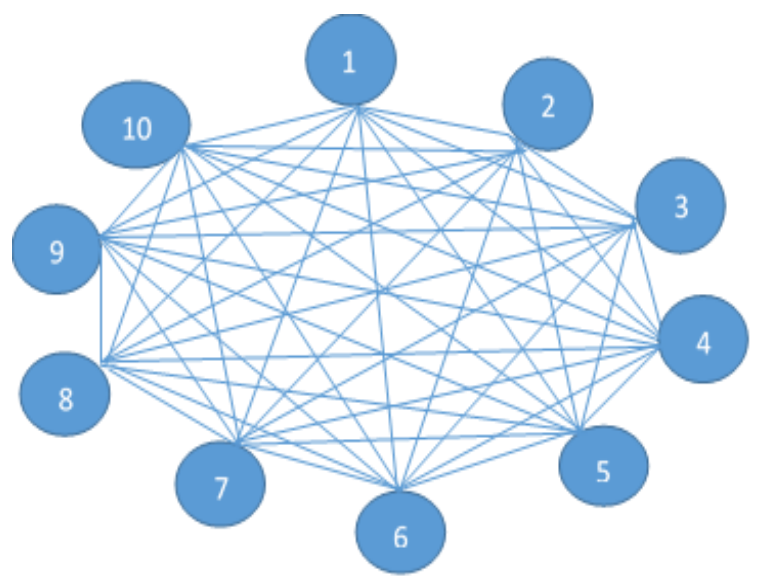

Gambar 1. Graf jarak

Ket :

1. Gonzalo

2. Jalan Pattimura

3. Jalan WR. Supratman

4. Jalan A. Yani

5. Jalan Dr. kayadoe 

6. Jalan Pitu ina
7. Jalan Karang Panjang
8. Jalan Said perintah
9. Jalan A Y Patty
10. Terminal Mardika

Dalam melakukan pencarian jalur terpendek dengan menggunakan Algoritma Backtracking kita akan mengasumsikannya seperti mencari nilai minimun dari sirkuit hamilton yang berawal dan berakhir dari titik 1 . Untuk mempercepat pencarian maka kita dapat menambahkan fungsi pembatas, dimana fungsi pembatas dapat direpresentasikan dengan matriks bobot yang direduksi untuk mendapatkan batasnya.

Dimana matriks bobot dapat dibentuk dengan cara sebagai berikut:
a. $\quad M(i, j)=$ bobot dari simpul $\mathrm{i}$ ke j
b. $M(i, j)=\infty$, jika tidak ada simpul dari i ke j

Maka berdasarkan data pada Gambar 1 matriks bobot yang diperoleh adalah sebagai berikut:

$$
M=\left[\begin{array}{llllllllll}
\infty & 4,3 & 4,9 & 4,2 & 4,3 & 3 & 2,4 & 4,5 & 6,6 & 4,8 \\
4,1 & \infty & 1 & 0,091 & 0,66 & 1,8 & 2,3 & 0,599 & 2,9 & 1,2 \\
4,9 & 1,1 & \infty & 1,1 & 1,7 & 2 & 2,8 & 0,887 & 2,4 & 0,888 \\
4,2 & 1,2 & 0,917 & \infty & 1,8 & 2,8 & 3,6 & 0,67 & 2,8 & 1,7 \\
4,2 & 0,875 & 0,804 & 0,966 & \infty & 1,7 & 2,5 & 0,708 & 2,8 & 0,579 \\
3 & 1,1 & 1,9 & 1,2 & 1,2 & \infty & 0,568 & 1,5 & 3,6 & 1,8 \\
2,4 & 1,7 & 2,5 & 1,8 & 1,8 & 0,568 & \infty & 2,1 & 4,2 & 2,4 \\
4,5 & 0,669 & 0,408 & 0,76 & 1,3 & 2,3 & 3,1 & \infty & 2,1 & 1,2 \\
6,6 & 2,8 & 2,4 & 2,9 & 3,4 & 4,3 & 5,3 & 2,4 & \infty & 3,3 \\
5,2 & 1,5 & 0,794 & 1,6 & 2,1 & 2,4 & 3,2 & 1,3 & 3,2 & \infty
\end{array}\right]
$$

\subsubsection{Pembentukan Simpul Akar}

Karena Algoritma Backtracking merupakan agoritma yang melakukan pencarian solusi pada pohon ruang status maka pertama - tama akan kita bentuk simpul akar dimana dari matriks bobot yang ada akan di buat simpul akar atau simpul induk dengan mereduksi matriks bobot tersebut, untuk memperoleh batas dari simpul akar tersebut, dimana suatu matriks bobot dikatakan tereduksi jika setiap baris dan kolom memuat paling sedikit satu angka 0 , sehingga dari matriks bobot berikut:

$$
M=\left[\begin{array}{llllllllll}
\infty & 4,3 & 4,9 & 4,2 & 4,3 & 3 & 2,4 & 4,5 & 6,6 & 4,8 \\
4,1 & \infty & 1 & 0,091 & 0,66 & 1,8 & 2,3 & 0,599 & 2,9 & 1,2 \\
4,9 & 1,1 & \infty & 1,1 & 1,7 & 2 & 2,8 & 0,887 & 2,4 & 0,888 \\
4,2 & 1,2 & 0,917 & \infty & 1,8 & 2,8 & 3,6 & 0,67 & 2,8 & 1,7 \\
4,2 & 0,875 & 0,804 & 0,966 & \infty & 1,7 & 2,5 & 0,708 & 2,8 & 0,579 \\
3 & 1,1 & 1,9 & 1,2 & 1,2 & \infty & 0,568 & 1,5 & 3,6 & 1,8 \\
2,4 & 1,7 & 2,5 & 1,8 & 1,8 & 0,568 & \infty & 2,1 & 4,2 & 2,4 \\
4,5 & 0,669 & 0,408 & 0,76 & 1,3 & 2,3 & 3,1 & \infty & 2,1 & 1,2 \\
6,6 & 2,8 & 2,4 & 2,9 & 3,4 & 4,3 & 5,3 & 2,4 & \infty & 3,3 \\
5,2 & 1,5 & 0,794 & 1,6 & 2,1 & 2,4 & 3,2 & 1,3 & 3,2 & \infty
\end{array}\right]
$$


Reduksi baris:

Reduksi baris dilakukan dengan mengurangi setiap baris dengan nilai terkecil dari baris tersebut sehingga untuk matriks bobot yaitu :

$$
M=\left[\begin{array}{llllllllll}
\infty & 4,3 & 4,9 & 4,2 & 4,3 & 3 & 2,4 & 4,5 & 6,6 & 4,8 \\
4,1 & \infty & 1 & 0,091 & 0,66 & 1,8 & 2,3 & 0,599 & 2,9 & 1,2 \\
4,9 & 1,1 & \infty & 1,1 & 1,7 & 2 & 2,8 & 0,887 & 2,4 & 0,888 \\
4,2 & 1,2 & 0,917 & \infty & 1,8 & 2,8 & 3,6 & 0,67 & 2,8 & 1,7 \\
4,2 & 0,875 & 0,804 & 0,966 & \infty & 1,7 & 2,5 & 0,708 & 2,8 & 0,579 \\
3 & 1,1 & 1,9 & 1,2 & 1,2 & \infty & 0,568 & 1,5 & 3,6 & 1,8 \\
2,4 & 1,7 & 2,5 & 1,8 & 1,8 & 0,568 & \infty & 2,1 & 4,2 & 2,4 \\
4,5 & 0,669 & 0,408 & 0,76 & 1,3 & 2,3 & 3,1 & \infty & 2,1 & 1,2 \\
6,6 & 2,8 & 2,4 & 2,9 & 3,4 & 4,3 & 5,3 & 2,4 & \infty & 3,3 \\
5,2 & 1,5 & 0,794 & 1,6 & 2,1 & 2,4 & 3,2 & 1,3 & 3,2 & \infty
\end{array}\right]
$$

Langkah berikut merupakan proses reduksi masing-masing baris:

baris ke 1, direduksi dengan 2.4

baris ke 2 , direduksi dengan 0.091

baris ke 3 , direduksi dengan 0.887

baris ke 4, direduksi dengan 0.67

baris ke 5, direduksi dengan 0.579

baris ke 6 , direduksi dengan 0.568

baris ke 7 , direduksi dengan 0.568

baris ke 8 , direduksi dengan 0.408

baris ke 9 , direduksi dengan 2.4

baris ke 10, direduksi dengan 0.794

sehingga menghasilkan matriks baru yaitu matriks $M^{\prime}$ yang merupakan matriks hasil reduksi baris dari matriks $M$ yaitu:

$$
M^{\prime}=\left[\begin{array}{llllllllll}
\infty & 1,9 & 2,5 & 1,8 & 1,9 & 0,6 & 0 & 2,1 & 4,2 & 2,4 \\
4,009 & \infty & 0,909 & 0 & 0,569 & 1,709 & 2,209 & 0,508 & 2,809 & 1,109 \\
4,013 & 0,213 & \infty & 0,213 & 0,813 & 1,113 & 1,913 & 0 & 1,513 & 0,001 \\
3,53 & 0,53 & 0,247 & \infty & 1,13 & 2,13 & 2,93 & 0 & 2,13 & 1,03 \\
3,621 & 0,296 & 0,225 & 0,387 & \infty & 1,121 & 1,921 & 0,129 & 2,221 & 0 \\
2,432 & 0,532 & 1,332 & 0,632 & 0,632 & \infty & 0 & 0,932 & 3,032 & 1,232 \\
1,832 & 1,132 & 1,932 & 1,232 & 1,232 & 0 & \infty & 1,532 & 3,632 & 1,832 \\
4,092 & 0,261 & 0 & 0,352 & 0,892 & 1,892 & 2,692 & \infty & 1,692 & 0,792 \\
4,2 & 0,4 & 0 & 0,5 & 1 & 1,9 & 2,9 & 0 & \infty & 0,9 \\
4,406 & 0,706 & 0 & 0,806 & 1,306 & 1,606 & 2,406 & 0,506 & 2,406 & \infty
\end{array}\right]
$$

Selanjutnya matriks $M^{\prime}$ akan direduksi kolomnya.

\section{Reduksi kolom:}

Sama halnya dengan reduksi baris reduksi kolom dilakukan dengan mengurangi setiap kolom yang ada dengan nilai terkecil dari kolom tersebut, sehingga untuk Matriks $M^{\prime}$ yaitu: 


$$
M^{\prime}=\left[\begin{array}{llllllllll}
\infty & 1,9 & 2,5 & 1,8 & 1,9 & 0,6 & 0 & 2,1 & 4,2 & 2,4 \\
4,009 & \infty & 0,909 & 0 & 0,569 & 1,709 & 2,209 & 0,508 & 2,809 & 1,109 \\
4,013 & 0,213 & \infty & 0,213 & 0,813 & 1,113 & 1,913 & 0 & 1,513 & 0,001 \\
3,53 & 0,53 & 0,247 & \infty & 1,13 & 2,13 & 2,93 & 0 & 2,13 & 1,03 \\
3,621 & 0,296 & 0,225 & 0,387 & \infty & 1,121 & 1,921 & 0,129 & 2,221 & 0 \\
2,432 & 0,532 & 1,332 & 0,632 & 0,632 & \infty & 0 & 0,932 & 3,032 & 1,232 \\
1,832 & 1,132 & 1,932 & 1,232 & 1,232 & 0 & \infty & 1,532 & 3,632 & 1,832 \\
4,092 & 0,261 & 0 & 0,352 & 0,892 & 1,892 & 2,692 & \infty & 1,692 & 0,792 \\
4,2 & 0,4 & 0 & 0,5 & 1 & 1,9 & 2,9 & 0 & \infty & 0,9 \\
4,406 & 0,706 & 0 & 0,806 & 1,306 & 1,606 & 2,406 & 0,506 & 2,406 & \infty
\end{array}\right]
$$

Langkah berikut merupakan proses reduksi masing-masing baris:

kolom ke 1 , direduksi dengan 1.832

kolom ke 2 , direduksi dengan 0.213

kolom ke 3 , direduksi dengan 0

kolom ke 4 , direduksi dengan 0

kolom ke 5 , direduksi dengan 0.569

kolom ke 6 , direduksi dengan 0

kolom ke 7 , direduksi dengan 0

kolom ke 8 , direduksi dengan 0

kolom ke 9 , direduksi dengan 1.513

kolom ke 10 , direduksi dengan 0

Sehingga menghasilkan matriks baru yaitu :

$$
M^{\prime \prime}=\left[\begin{array}{llllllllll}
\infty & 1,687 & 2,5 & 1,8 & 1,331 & 0,6 & 0 & 2,1 & 2,687 & 2,4 \\
2,177 & \infty & 0,909 & 0 & 0 & 1,709 & 2,209 & 0,508 & 1,296 & 1,109 \\
2,181 & 0 & \infty & 0,213 & 0,244 & 1,113 & 1,913 & 0 & 0 & 0,001 \\
1,698 & 0,317 & 0,247 & \infty & 0,561 & 2,13 & 2,93 & 0 & 0,617 & 1,03 \\
1,789 & 0,083 & 0,225 & 0,387 & \infty & 1,121 & 1,921 & 0,129 & 0,708 & 0 \\
0,6 & 0,319 & 1,332 & 0,632 & 0,063 & \infty & 0 & 0,932 & 1,519 & 1,232 \\
0 & 0,919 & 1,932 & 1,232 & 0,663 & 0 & \infty & 1,532 & 2,119 & 1,832 \\
2,26 & 0,048 & 0 & 0,352 & 0,323 & 1,892 & 2,692 & \infty & 0,179 & 0,792 \\
2,368 & 0,187 & 0 & 0,5 & 0,431 & 1,9 & 2,9 & 0 & \infty & 0,9 \\
2,574 & 0,493 & 0 & 0,806 & 0,737 & 1,606 & 2,406 & 0,506 & 0,893 & \infty
\end{array}\right]
$$

Maka batas dari simpul akar diperoleh dari penjumlahan hasil reduksi baris dan kolom dari matriks bobot yaitu :

$$
\begin{aligned}
c(\text { root })= & 2,4+0,091+0,887+0,67+0,579+0,568+0,568+0,408+2,4+0,794+1,832+0,213+0+0+0,569 \\
& +0+0+0+1,513+0=13,492
\end{aligned}
$$

Sehingga simpul akar yang terbentuk mempunyai batas yaitu 13,492 


\subsubsection{Pembangkitan simpul anak}

Setelah kita membentuk simpul akar maka langkah selanjutnya adalah membangkitkan simpul anak dari simpul akar tersebut dengan cara sebagai berikut:

Misal A adalah matriks tereduksi untuk simpul R dan misalkan $S$ adalah anak dari simpul R sehingga sisi $(\mathrm{R}, \mathrm{S})$ pada pohon ruang status berkorespondensi dengan sisi $(i, j)$. Lakukan langkah-langkah berikut :
a. Mengubah semua nilai dari baris $i$ dan $\operatorname{kolom} j$ menjadi $\infty$
b. Mengubah $A(j, 1)$ menjadi $\infty$
c. Reduksi kembali matriks A

Reduksi matriks A akan menghasilkan matriks lain (misal, B) dan fungsi pembatas. Secara umum, persamaan fungsi pembatas adalah:

$$
c(S)=c(R)+A(i, j)+r
$$

dengan

$$
\begin{aligned}
& c(S)=\text { bobot perjalanan minimum yang melalui simpul } S \text { (simpul di pohon ruang status) } \\
& c(R)=\text { bobot perjalanan minimum yang melalui simpul } R \text {, yang dalam hal ini R adalah orangtua dari } S . \\
& A(i, j)=\text { bobot sisi }(i, j) \text { pada graf } \mathrm{G} \text { yang berkoresponden dengan sisi }(R, S) \text { pada pohon ruang status. } \\
& r=\text { jumlah semua pengurang pada proses memperoleh matriks tereduksi untuk simpul } S .
\end{aligned}
$$

Maka berdasarkan data pada Gambar 1 maka simpul anak yang akan dibangun adalah simpul 2, 3, 4, 5, 6, 7, 8, 9, dan 10 yaitu:

\section{Simpul 2, lintasan 1 ke 2}

Dengan menggunakan langkah - langkah A dan B pada pembangkitan simpul anak maka matriks yang merepresentasikan lintasan 1 ke 2 adalah:

$$
M^{\prime}{ }_{12}=\left[\begin{array}{llllllllll}
\infty & \infty & \infty & \infty & \infty & \infty & \infty & \infty & \infty & \infty \\
\infty & \infty & 0,909 & 0 & 0 & 1,709 & 2,209 & 0,508 & 1,296 & 1,109 \\
2,181 & \infty & \infty & 0,213 & 0,244 & 1,113 & 1,913 & 0 & 0 & 0,001 \\
1,698 & \infty & 0,247 & \infty & 0,561 & 2,13 & 2,93 & 0 & 0,617 & 1,03 \\
1,789 & \infty & 0,225 & 0,387 & \infty & 1,121 & 1,921 & 0,129 & 0,708 & 0 \\
0,6 & \infty & 1,332 & 0,632 & 0,063 & \infty & 0 & 0,932 & 1,519 & 1,232 \\
0 & \infty & 1,932 & 1,232 & 0,663 & 0 & \infty & 1,532 & 2,119 & 1,832 \\
2,26 & \infty & 0 & 0,352 & 0,323 & 1,892 & 2,692 & \infty & 0,179 & 0,792 \\
2,368 & \infty & 0 & 0,5 & 0,431 & 1,9 & 2,9 & 0 & \infty & 0,9 \\
2,574 & \infty & 0 & 0,806 & 0,737 & 1,606 & 2,406 & 0,506 & 0,893 & \infty
\end{array}\right]
$$

Selanjutnya matriks $M^{\prime}{ }_{12}$ akan di reduksi kembali untuk memperoleh batas dari lintasan 1 ke 2

Reduksi matriks $M^{\prime}{ }_{12}$ :

Pada matriks $M^{\prime}{ }_{12}$ dapat dilihat bahwa pada setiap baris dan kolom pada matriks tersebut mempunyai paling sedikit 1 nilai 0 sehingga total hasil reduksi matriksnya adalah 0 , dengan matriks setelah direduksi baris dan kolom adalah 


$$
M^{\prime \prime}{ }_{12}=\left[\begin{array}{llllllllll}
\infty & \infty & \infty & \infty & \infty & \infty & \infty & \infty & \infty & \infty \\
\infty & \infty & 0,909 & 0 & 0 & 1,709 & 2,209 & 0,508 & 1,296 & 1,109 \\
2,181 & \infty & \infty & 0,213 & 0,244 & 1,113 & 1,913 & 0 & 0 & 0,001 \\
1,698 & \infty & 0,247 & \infty & 0,561 & 2,13 & 2,93 & 0 & 0,617 & 1,03 \\
1,789 & \infty & 0,225 & 0,387 & \infty & 1,121 & 1,921 & 0,129 & 0,708 & 0 \\
0,6 & \infty & 1,332 & 0,632 & 0,063 & \infty & 0 & 0,932 & 1,519 & 1,232 \\
0 & \infty & 1,932 & 1,232 & 0,663 & 0 & \infty & 1,532 & 2,119 & 1,832 \\
2,26 & \infty & 0 & 0,352 & 0,323 & 1,892 & 2,692 & \infty & 0,179 & 0,792 \\
2,368 & \infty & 0 & 0,5 & 0,431 & 1,9 & 2,9 & 0 & \infty & 0,9 \\
2,574 & \infty & 0 & 0,806 & 0,737 & 1,606 & 2,406 & 0,506 & 0,893 & \infty
\end{array}\right]
$$

Maka batas dari simpul 2 dengan menggunakan persamaan fungsi pembatas pada pembangkitan simpul anak dengan diketahui bahwa bobot perjalanan minimum dari simpul induk adalah 13,492 dan bobot sisi yang berkorespondensi adalah 1,687 serta total pengurangan pada proses reduksi adalah 0 , sehingga:

$$
\begin{gathered}
\mathrm{c}(2)=\mathrm{c}(\text { root })+M^{\prime \prime}(1,2)+r \\
\quad \text { adalah : } \\
\mathrm{c}(2)=13,492+1,687+0=15,179
\end{gathered}
$$

\section{Simpul 3, lintasan 1 ke 3}

Sama halnya dengan lintasan 1 ke 2 pada lintasan 1 ke 3 dengan mengikuti langkah - langkah A dan B pada pembangkitan simpul anak maka matriks yang merepresentasikan lintasan 1 ke 3 adalah:

$$
M^{\prime}{ }^{\prime}=\left[\begin{array}{llllllllll}
\infty & \infty & \infty & \infty & \infty & \infty & \infty & \infty & \infty & \infty \\
2,177 & \infty & \infty & 0 & 0 & 1,709 & 2,209 & 0,508 & 1,296 & 1,109 \\
\infty & 0 & \infty & 0,213 & 0,244 & 1,113 & 1,913 & 0 & 0 & 0,001 \\
1,698 & 0,317 & \infty & \infty & 0,561 & 2,13 & 2,93 & 0 & 0,617 & 1,03 \\
1,789 & 0,083 & \infty & 0,387 & \infty & 1,121 & 1,921 & 0,129 & 0,708 & 0 \\
0,6 & 0,319 & \infty & 0,632 & 0,063 & \infty & 0 & 0,932 & 1,519 & 1,232 \\
0 & 0,919 & \infty & 1,232 & 0,663 & 0 & \infty & 1,532 & 2,119 & 1,832 \\
2,26 & 0,048 & \infty & 0,352 & 0,323 & 1,892 & 2,692 & \infty & 0,179 & 0,792 \\
2,368 & 0,187 & \infty & 0,5 & 0,431 & 1,9 & 2,9 & 0 & \infty & 0,9
\end{array}\right]
$$

Selanjutnya matrik $M_{13}^{\prime}$ akan direduksi sebagai berikut:

Baris ke 8 , direduksi dengan 0.048

Baris ke 10 , direduksi dengan 0.493

Dengan matriks setelah direduksi adalah sebagai berikut:

$$
M^{\prime \prime}{ }_{13}=\left[\begin{array}{llllllllll}
\infty & \infty & \infty & \infty & \infty & \infty & \infty & \infty & \infty & \infty \\
2,177 & \infty & \infty & 0 & 0 & 1,709 & 2,209 & 0,508 & 1,296 & 1,109 \\
\infty & 0 & \infty & 0,213 & 0,244 & 1,113 & 1,913 & 0 & 0 & 0,001 \\
1,698 & 0,317 & \infty & \infty & 0,561 & 2,13 & 2,93 & 0 & 0,617 & 1,03 \\
1,789 & 0,083 & \infty & 0,387 & \infty & 1,121 & 1,921 & 0,129 & 0,708 & 0 \\
0,6 & 0,319 & \infty & 0,632 & 0,063 & \infty & 0 & 0,932 & 1,519 & 1,232 \\
0 & 0,919 & \infty & 1,232 & 0,663 & 0 & \infty & 1,532 & 2,119 & 1,832 \\
2,212 & 0 & \infty & 0,304 & 0,275 & 1,844 & 2,644 & \infty & 0,131 & 0,744 \\
2,368 & 0,187 & \infty & 0,5 & 0,431 & 1,9 & 2,9 & 0 & \infty & 0,9 \\
2,081 & 0 & \infty & 0,313 & 0,244 & 1,113 & 1,913 & 0,013 & 0,4 & \infty
\end{array}\right]
$$

Maka batas dari simpul 3 dengan menggunakan persamaan fungsi pembatas pada pembangkitan simpul anak dengan diketahui bahwa bobot perjalanan minimum dari simpul induk adalah 13,492 dan bobot sisi yang berkorespondensi adalah 2,5 serta total pengurangan pada proses reduksi adalah 0,541 , sehingga:

$$
c(2)=c(\text { root })+M^{\prime \prime}(1,3)+r
$$

adalah:

$$
c(3)=13,492+2,5+0,541=16,533
$$


untuk simpul 4, 5, 6, 7, 8, 9, 10 dilakukan hal yang sama seperti pada simpul 2 dan 3 sehingga sesuai dengan data pada lampiran 1 maka diperoleh:

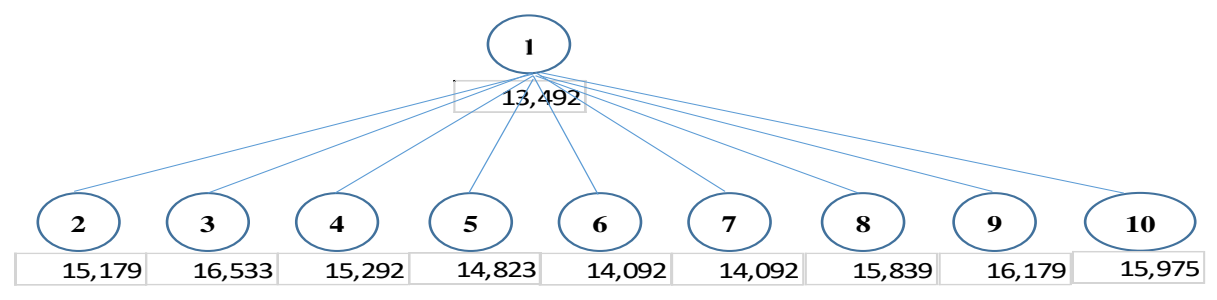

Gambar 2. Hasil pembangkitan simpul anak

Karena tujuan kita adalah untuk mendapatkan rute yang minimum maka simpul anak yang akan di proses lagi adalah simpul anak dengan batas terkecil dimana berdasarkan Gambar 2 maka simpul anak yang akan di proses lagi adalah simpul ke 6 dan simpul ke 7, sehingga dengan menjadikan simpul ke 6 dan ke 7 sebagai simpul induk maka akan dibangkitkan simpul anak dari simpul ke 6 dan 7, dan dengan mengulangi langkah - langkah pada pembangkitan simpul anak sampai tidak ada lagi simpul anak yang dibangkitkan maka sesuai dengan data pada lampiran 1 diperoleh rute minimumnya adalah $1-7-6-5-10-3-9-8-2-4$ atau Gonzalo - Jln. Karang panjang - Jln. Pitu ina Jln. Dr. Kayadoe - Terminal mardika - Jln. Wr. Supratman - Jln. A.Y. Patty - Jln. Said Perintah - Jln. Pattimura Jln A. Yani - Gonzalo dengan panjang rutenya adalah 15,301 Km. Yang menghasilkan jarak tempuh yang lebih minimum dibandingkan dengan rute yang biasanya diambil oleh tempat pengisian Air Isi Ulang Gonzalo yaitu Gonzalo - Jln Pitu ina - Jln karang panjang - Jln Wr supratman - Jln Pattimura - Jln A. Yani - Jln Dr. Kayadoe Jln said perintah - Jln A.Y. patty - Terminal mardika - Gonzalo dengan panjang 20,367 Km.

\subsection{Analisis dengan software Matlab}

Untuk mempermudah proses perhitungan dan analisa digunakan aplikasi GUI Matlab untuk merancang tampilan visual antarmuka dari aplikasi Algoritma Backtracking dalam menghitung rute optimal pendistribusian air isi ulang Gonzalo di kota Ambon dengan menggunakan perangkat lunak (software) Matlab R2009, dengan hasil programnya dapat dilihat pada Gambar 3 berikut:

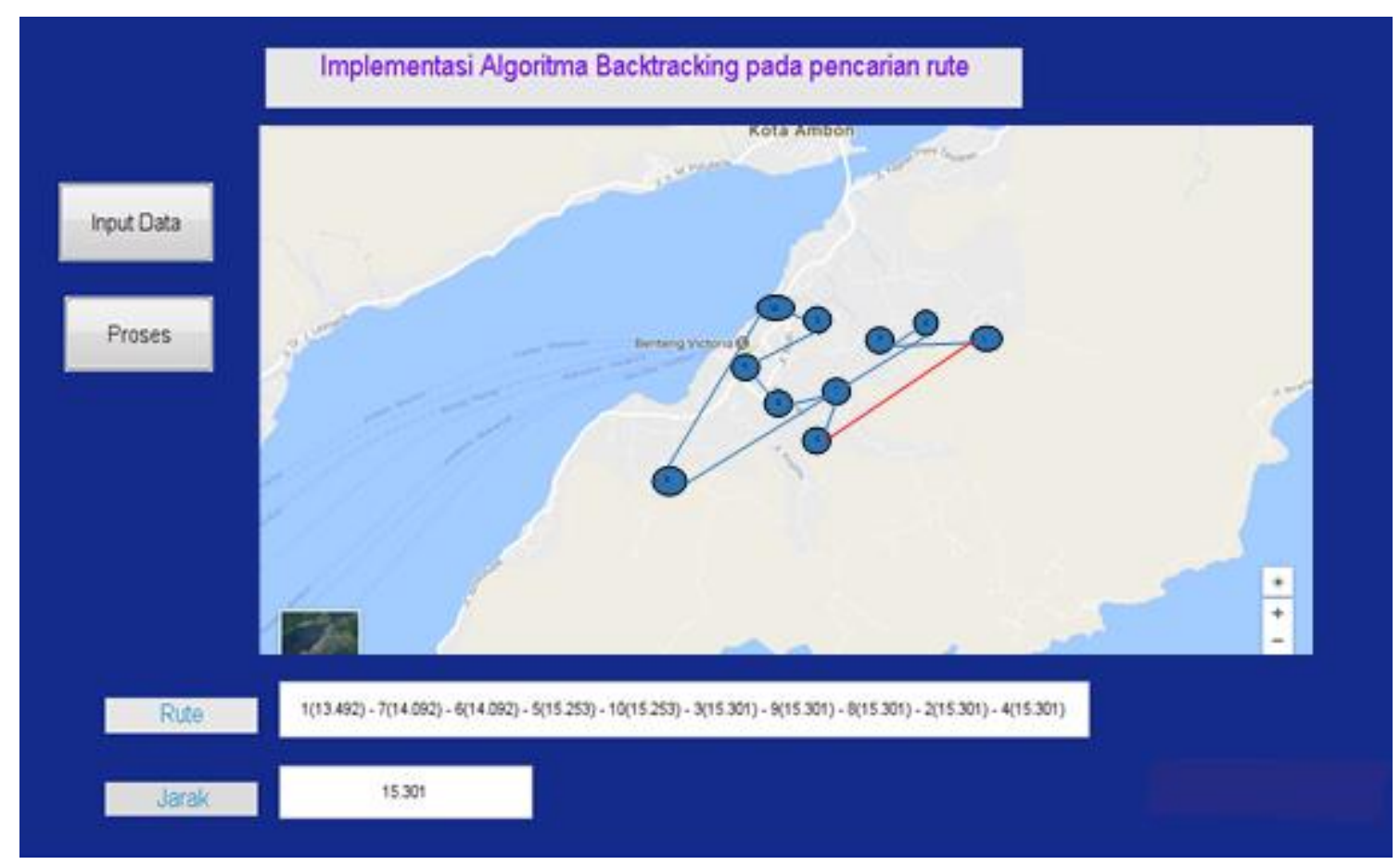

Gambar 3. Aplikasi Pencarian Rute Optimum dengan Algoritma Backtracking dengan GUI Matlab 
Dari hasil pemograman di atas dapat dilihat bahwa rute terpendek dalam pendistribusian air isi ulang adalah melalui Gonzalo - Jln. Karang Panjang - Jln. Pitu Ina - Jln. Dr. Kayadoe - Terminal Mardika - Jln. Wr. Supratman - Jln. A.Y. Patty - Jln. Said Perintah - Jln. Pattimura - Jln A. Yani - Gonzalo. Sehingga panjang rute perjalanan optimal adalah $15,301 \mathrm{Km}$,

\section{KESIMPULAN}

Dari hasil dan uraian diatas maka dapat diambil beberapa kesimpulan sebagai berikut: Rute Optimum Pendistribusian Air Isi Ulang Gonzalo adalah melalui Gonzalo, Jln. Karang Panjang, Jln. Pitu Ina, Jln. Dr. Kayadoe, Terminal Mardika, Jln. WR. Supratman, Jln. A.Y. Patty, Jln. Said Perintah, Jln. Pattimura, Jln A. Yani - Gonzalo. Dengan panjang rute perjalanan adalah $15,301 \mathrm{Km}$.

\section{DAFTAR PUSTAKA}

[1] D. L. Applegate, R. E. Bixby, V. Chvátal, and W. J. Cook, The traveling salesman problem: A computational study. 2011.

[2] "The traveling-salesman problem," Math. Sci. Eng., 1977.

[3] T. Bektas, "The multiple traveling salesman problem: An overview of formulations and solution procedures," Omega, 2006.

[4] G. Gutin and A. Punnen, "The Traveling Salesman Problem and its Variations," ... Comb. Optim. Probl. ..., 2007.

[5] E. Balas, "The prize collecting traveling salesman problem," Networks, 1989.

[6] D. Feillet, P. Dejax, and M. Gendreau, "Traveling salesman problems with profits," Transp. Sci., 2005.

[7] C. E. Miller, R. A. Zemlin, and A. W. Tucker, "Integer Programming Formulation of Traveling Salesman Problems," J. ACM, 1960.

[8] G. Laporte, “A concise guide to the Traveling Salesman Problem,” J. Oper. Res. Soc., 2010.

[9] Y. Dumas, J. Desrosiers, E. Gelinas, and M. M. Solomon, “An Optimal Algorithm for the Traveling Salesman Problem with Time Windows,” Oper. Res., 1995.

[10] H. Murti, E. Supriyanto, and S. Sugiyamta, "Optimalisasi Pencarian Lintasan Traveling Salesman Problem Menggunakan Algoritma Backtracking," Dinamik, 2019.

[11] E. Elvina and L. Hakim, "Modifikasi Algoritma Steepest-Ascent Hill Climbing Dan Backtracking Untuk Pencarian Lintasan Kritis Proyek,” CogITo Smart J., 2019.

[12] D. C. Schmidt and L. E. Druffel, “A Fast Backtracking Algorithm to Test Directed Graphs for Isomorphism Using Distance Matrices," J. ACM, 1976.

[13] "Genetic algorithms in search, optimization, and machine learning," Choice Rev. Online, 1989.

[14] M. Kumar, M. Husian, N. Upreti, and D. Gupta, "Genetic Algorithm: Review And Application," Int. J. Inf. Technol., 2010.

[15] S. Forrest, "Genetic algorithms," in Computer Science Handbook, Second Edition, 2004.

[16] O. Kramer, "Genetic Algorithm Essentials,” Springer Int. Publ. AG, 2017.

[17] S. Kirkpatrick, C. D. Gelatt, and M. P. Vecchi, “Optimization by simulated annealing,” Science (80-. )., 1983.

[18] K. A. Dowsland and J. M. Thompson, "Simulated annealing," in Handbook of Natural Computing, 2012.

[19] E. Aarts, J. Korst, and W. Michiels, "Simulated annealing," in Search Methodologies: Introductory Tutorials in Optimization and Decision Support Techniques, 2005.

[20] D. E. Knuth and M. F. Plass, "Breaking paragraphs into lines," Softw. Pract. Exp., 1981.

[21] T. Teneng, J. Purwadi, and E. Kurniawan, "Penerapan Algoritma Backtracking Pada Permainan Math Maze," J. Inform., 2011.

[22] R. Dewi and I. Sari, “Analisis Penyelesaian Puzzle Sudoku Dengan Menerapkan Algoritma Backtracking," Konf. Nas. "Inovasi dalam Desain dan Teknol., 2011.

[23] W. A. Arifiyanto, "Penggunaan Algoritma Backtracking Dalam Penyelesaian Permainan Sudoku,” J. Inform., 2007.

[24] S. Mujaddid, "Penerapan Algoritma Runut-Balik ( Backtracking ) Dalam Penyelesaian Permainan Sudoku," Makal. IF3051 Strateg. Algoritm., 2009. 